\title{
Selective settlement by larvae of Membranipora membranacea and Electra pilosa (Ectoprocta) along kelp blades in Nova Scotia, Canada
}

\author{
Danielle Denley ${ }^{1, *}$, Anna Metaxas ${ }^{1}$, Jessie Short ${ }^{1,2}$ \\ ${ }^{1}$ Department of Oceanography, Dalhousie University, Halifax, Nova Scotia, Canada, B3H 4R2 \\ ${ }^{2}$ Present address: Oceans Institute and School of Earth and Environment, ARC Centre of Excellence for Coral Reef Studies, \\ University of Western Australia, Crawley, Western Australia 6009, Australia
}

\begin{abstract}
Many larval sessile marine invertebrates exhibit settlement preferences, and larval behavioral responses to cues at settlement can ultimately influence the distribution of adults and an individual's lifetime fitness. Two epifaunal bryozoans, the invasive Membranipora membranacea and the native Electra pilosa, commonly co-occur on kelp species in the subtidal habitats of Nova Scotia, Canada. Outbreaks of M. membranacea have been linked to mass defoliation of the kelp canopy; however, E. pilosa has not been associated with any significant effect on its host substrate. To examine whether larvae of $M$. membranacea and E. pilosa exhibit settlement preference for a particular location along the blades of the kelps Saccharina latissima and Laminaria digitata, abundances of newly settled colonies were quantified at different locations along the kelp blade. Algae were sampled at 2 sites on the southwestern shore of Nova Scotia (The Lodge and Feltzen South) from September 2009 to October 2010, over one complete cycle of the annual life cycle of $M$. membranacea, and thus over a wide range of bryozoan percent cover. Settlers of both bryozoans were significantly more abundant towards the younger, more proximal regions of blades of both kelps across all sampling periods. These patterns did not vary seasonally with increasing colony density. Both $M$. membranacea and E. pilosa larvae showed preferential settlement, suggesting that they can detect small-scale differences in habitat quality at the scale of a single kelp blade.
\end{abstract}

KEY WORDS: Invasive species · Settlement preference - Invertebrate larvae $\cdot$ Ephemeral habitats · Settlement cues

\section{INTRODUCTION}

Spatial patterns in the distribution and abundance of sessile marine invertebrates with planktonic larvae are controlled in part by the non-random settlement of recruiting larvae onto substrates suitable for adult life (Hadfield 1986, Chia 1989). Consequently, substrate selection by planktonic larvae is a key process in the life history of benthic invertebrates, strongly influencing critical population parameters, such as postsettlement mortality (Keough \& Downes 1982) and,

${ }^{*}$ Corresponding author: danielle.denley@dal.ca ultimately, adult population density (Minchinton \& Scheibling 1991). Larvae of many benthic invertebrates display clear preferences for specific substrates (Burke 1983). However, the small size of planktonic larvae relative to the substrate onto which they are settling makes it possible for gradients in microhabitat to exist within a given substrate (Seed \& O'Connor 1981). This small-scale variability in habitat quality becomes particularly interesting on biologically dynamic substrates such as macroalgae, where variation in habitat occurs not only spatially, but also temporally.

() The authors 2014. Open Access under Creative Commons by Attribution Licence. Use, distribution and reproduction are unrestricted. Authors and original publication must be credited. 
Blades of laminarian algae are continually growing from the proximal end and eroding from the distal end, and the blade tissue can be entirely recycled between 1 and 5 times a year depending on temperature (Mann 1973). Consequently, while a kelp bed may persist for decades, the available habitat to an epiphyte colonizing an individual kelp blade is constantly changing. The successful recruitment and overall lifetime fitness of epiphytes on such ephemeral habitats is often related to the location of settlement on the alga (Keough 1986, Durante \& Chia 1991), and as a result, larvae of marine epiphytes on macroalgae exhibit a range of settlement preferences (Hayward \& Harvey 1974, Bernstein \& Jung 1979, Roland 1980, Durante \& Chia 1991).

In the subtidal habitats of Nova Scotia, the 2 most abundant bryozoan epiphytes are the recent invasive Membranipora membranacea (Watanabe et al. 2010) and the native Electra pilosa. M. membranacea is an encrusting colonial bryozoan and was first observed in the Gulf of Maine (USA) in 1987, where it facilitated significant alterations of the local marine community, establishing itself as the dominant epiphyte on laminarian kelps in as little as 2 yr (Berman et al. 1992, Lambert et al. 1992). Off the southwestern shore of Nova Scotia, small colonies of M. membranacea were first found in 1992 and had similar dramatic effects, as rapid growth resulted in major loss of kelp canopy within 1 yr (Scheibling et al. 1999). M. membranacea has an annual life cycle. In Nova Scotia, $M$. membranacea larvae typically settle between May and July with peak settlement occurring in September (Saunders \& Metaxas 2007). Larvae of M. membranacea settle predominantly on kelp substrates (Yorke \& Metaxas 2012), where they metamorphose into a pair of filter feeding zooids (ancestrula) from which additional zooids bud asexually, forming sheet-like colonies. These colonies rapidly encrust the kelp blade, and colony growth and reproduction continue throughout the summer months (June to August), with maximum colony abundance (percent cover) occurring in fall (September to October) (Saunders \& Metaxas 2009a). Colonies begin to senesce in late fall and early winter (November and December), a process that is characterized by stasis and/or shrinkage, with $<1 \%$ of the population persisting overwinter, presumably providing the larval supply for the following season.

Encrustation by $M$. membranacea reduces the survival of its kelp host by causing degradation of the meristoderm, resulting in the weakening of kelp blades and increasing their susceptibility to breakage during strong wave action in late fall and winter
(Krumhansl et al. 2011). Settlement and recruitment of $M$. membranacea into the adult population is of particular interest in the northwestern Atlantic, where recurring outbreaks of this invasive species have catalyzed mass defoliation of kelp beds (Scheibling et al. 1999, Saunders \& Metaxas 2008, Scheibling \& Gagnon 2009).

In its native range in the northwestern Pacific, larvae of $M$. membranacea exhibit searching behavior by actively crawling from older distal regions to settle on younger more proximal regions along the blade of the kelp Nereocystis leutkeana (Matson et al. 2010). Seed (1976) provided limited evidence from 8 plants at a single location and time that these larvae may also settle in greater abundance towards the proximal end of blades of the laminarian Saccharina latissima. However, little is known about the distribution of settlers of $M$. membranacea outside of their native habitat, where interactions with native kelp and epiphyte species may affect larval settlement behavior.

The cheilostome E. pilosa is a native bryozoan, also epiphytic on kelp substrates in Nova Scotia. Although seasonal patterns of settler abundance for $E$. pilosa in this region are unknown, E. pilosa is generally more abundant on Fucus species. This is in contrast to $M$. membranacea, which is relatively more abundant on kelps (Yorke \& Metaxas 2011). E. pilosa is also characterized by slower growth rates and smaller colony size and colony cover on kelp than $M$. membranacea (Yorke \& Metaxas 2011). While it is not known whether E. pilosa settles preferentially at a given location along the blade of its algal hosts, it has been suggested that larvae of E. pilosa settle gregariously (Ryland \& Stebbing 1971).

In Nova Scotia, M. membranacea and E. pilosa cooccur interspersed on blades of 2 of the most numerically abundant kelp species, S. latissima and Laminaria digitata (Yorke \& Metaxas 2011). Morphology and seasonal cycles of growth differ slightly between these 2 kelp species. S. latissima tends to have single, narrow blades with crenulated edges. It grows rapidly in spring (May), and slowly in fall (September to November) (Krumhansl \& Scheibling 2011). L. digitata has broad digitated blades. It follows a similar seasonal cycle in growth to $S$. latissima except that growth rate begins to increase earlier in the late winter and early spring (February to May) (Krumhansl \& Scheibling 2011). However, L. digitata grows considerably more slowly than $S$. latissima, with peak growth rates of the 2 species at optimal temperature $\left(10^{\circ} \mathrm{C}\right.$ ) differing by as much as $10 \% \mathrm{~d}^{-1}$ (Bolton \& Lüning 1982). 
In this study, we examined whether larvae of $M$. membranacea and E. pilosa exhibit preference for settling at a particular location along kelp blades at 2 locations in Nova Scotia. Because algae grow from the proximal towards the distal end, we compared abundances of newly settled individuals of each species in algal segments along the long axis of the blades of $S$. latissima and L. digitata. To determine whether any observed patterns in settlement varied temporally with colony density, we also quantified total cover of each bryozoan (\%) within each segment along the length of the kelp blade.

Our study extends that by Seed (1976) by capturing seasonal variation in the life cycles of both kelp and bryozoan species, as sampling occurs over the duration of an entire year. Our study was conducted in the northwest Atlantic where $M$. membranacea is invasive, and its recruitment may be limited to niches where resources are underused by the native epiphytes. To address potential effects on settlement, we examined patterns on both dominant kelps ( $S$. latissima and L. digitata) and for the most abundant bryozoans (E. pilosa and M. membranacea) in the region.

We hypothesized that, in the absence of a preference for settling at a particular location along the kelp blade based on tissue quality, settlers should be randomly distributed along the blade; any deviation from a random distribution may be related to other factors, such as colony density of $M$. membranacea. For M. membranacea specifically, colony density (percent cover) could influence patterns in the distribution of settlers in 1 of 2 ways: (1) gregarious settlement resulting in a positive relationship between abundance of settlers and percent cover of colonies; (2) conspecific avoidance or limiting space resulting in a negative relationship between settler abundance and percent cover of colonies. Conversely, if bryozoan larvae preferentially settle at a particular location along the kelp blade, abundance of settlers should be consistently high at this location, regardless of percent cover of colonies, and settlement preference should be detectable during periods of both high and low density of $M$. membranacea colonies.

\section{MATERIALS AND METHODS}

\section{Study area}

We sampled 2 sites on the southwestern shore of Nova Scotia, Canada, both of which were characterized by extensive mixed kelp beds dominated by Saccharina latissima and Laminaria digitata, and an un- derstory of turf algal species. The Lodge $\left(44^{\circ} 33^{\prime} 3^{\prime \prime} \mathrm{N}\right.$, $\left.64^{\circ} 01^{\prime} 9^{\prime \prime} \mathrm{W}\right)$ is located on the western shore of St. Margarets Bay and has a moderately steeply sloping granite substratum dominated by large boulders and cobbles, as well as beds of Fucus vesiculosus at depths $<4$ m. Feltzen South $\left(44^{\circ} 19^{\prime} 57^{\prime \prime}\right.$ N, 64 $\left.17^{\prime} 13^{\prime \prime} \mathrm{W}\right)$ is located on the southwestern shore of Lunenburg Bay, $30 \mathrm{~km}$ southwest of St. Margarets Bay, and has a gently sloping bedrock substratum dominated by cobbles and extensive beds of Fucus serratus. At The Lodge, sampling was done along 4, 8, and $12 \mathrm{~m}$ depth contours, while at Feltzen South, sampling was done at $9 \mathrm{~m}$ depth. The 2 sites were chosen based on previous studies showing differences in the relative abundance of Membranipora membranacea and Electra pilosa across different bays (Yorke \& Metaxas 2011).

\section{Collection of bryozoan colonies on kelps}

We sampled colonies of $M$. membranacea and $E$. pilosa on the kelps $S$. latissima and L. digitata once in October and November 2009, and September and December 2009 at The Lodge and Feltzen South respectively, and approximately bi-weekly from 25 June to 7 October 2010 at both sites. On each sampling date, $\sim 5$ blades (30 to $140 \mathrm{~cm}$ long) of each kelp species were haphazardly collected from each depth at each site, and transported to Dalhousie University in coolers, where they were frozen in plastic bags until processed.

\section{Quantification of bryozoans on algal blades}

For both kelp species, each blade was divided into $10-\mathrm{cm}$ zones perpendicular to the long axis of the blade from the stipe to the tip in increasing age of algal tissue ( 0 to $10 \mathrm{~cm}$ being the most proximal zone). In each $10-\mathrm{cm}$ zone and on both sides of the blade, percent cover of $M$. membranacea and E. pilosa colonies visible to the naked eye ( $>6$ to 10 zooid rows) was estimated in a haphazardly positioned circular area $($ diameter $=8.5 \mathrm{~cm}$ ). To evaluate the accuracy of this method of estimation of percent cover, visual estimates of percent cover for a subset of 6 kelps sampled in June and July 2010, and 9 kelps sampled in September, October, and November 2009, were compared with measurements of total bryozoan cover obtained using SigmaScan Pro 5 imaging software. Visual estimates and measurements acquired using imaging software were highly correlated $(y=$ $\left.1.09 x, r^{2}=0.94\right)$. 
To measure the abundance of newly settled individuals, the number of colonies consisting of 1.0 to 1.5 zooid rows was recorded in each of 5 circular areas (diameter $=2.6 \mathrm{~cm}$ ) positioned equidistantly from each other within each $10 \mathrm{~cm}$ zone on each of the $\sim 5$ (depending on availability of particular algal species in the field) individual blades collected for each kelp species on each sampling date, using a Nikon SMZ1500 stereomicroscope.

\section{Estimation of the age structure of the algal blade}

We used blade age to standardize the location of bryozoan colonies across species, depth, and sampling date. Estimates of blade age for $S$. latissima and L. digitata were calculated based on growth rates $\left(\mathrm{cm} \mathrm{d} \mathrm{d}^{-1}\right)$ measured using a hole punch method, where a hole is punched near the basal meristem of the kelp blade and growth rate is determined based on the distance the hole is displaced towards the distal end of the blade over a given period of time. Growth rates were calculated for each species ( $\mathrm{n}=10$ to 20) at 4 to $8 \mathrm{~m}$ depth at The Lodge in July, September, and November 2008, and in May and September 2009 (K. A. Krumhansl \& R. E. Scheibling unpubl. data). Growth rates for $S$. latissima ranged from $0.27 \mathrm{~cm} \mathrm{~d}^{-1}$ in July 2008 to $0.91 \mathrm{~cm} \mathrm{~d}^{-1}$ in May 2009, while growth rates for $L$. digitata ranged from $0.08 \mathrm{~cm} \mathrm{~d}^{-1}$ in September 2008 to $0.37 \mathrm{~cm} \mathrm{~d}^{-1}$ in May 2009. Because the available data on growth rates did not encompass all depths, sites, or sampling dates, growth rates were averaged across all months for each species to account for spatial and/or temporal variation. As a result, growth rate may have been underestimated in early spring and overestimated in early fall, particularly for $S$. latissima, the growth rate of which was more variable among sampling months ( $\mathrm{SD}=0.26$ and 0.14 , for S. latissima and L. digitata, respectively). The age of the algal tissue in each $10-\mathrm{cm}$ zone was then calculated by dividing the distance $(\mathrm{cm})$ of the leading edge of that zone from the base of the blade by the species-specific average growth rate $\left(\mathrm{cm} \mathrm{d}^{-1}\right)$.

\section{Data analysis}

To quantify settler abundance of $M$. membranacea and E. pilosa along the length of the kelp blade, the number of settlers was determined in each zone and then summed across zones and sides for each blade. The relative frequency of total settlers in each zone to the total number of settlers across all zones for all collected blades for each kelp species at each site was calculated for the following: (1) all sampling dates combined; and (2) for periods of high and low settler abundance and percent cover of $M$. membranacea (high settlement and percent cover: September 2010; low settlement and percent cover: combined June, July, and August 2010) and E. pilosa (high settlement: July 2010; low settlement: combined June and August 2010). Patterns in settler abundance along the length of kelp blades were consistent among bi-weekly sampling dates within the specified periods of high and low settlement and percent cover for $M$. membranacea and E. pilosa. Therefore, bi-weekly sampling dates were pooled into periods of high and low settlement and percent cover to increase the total number of settlers within each period. In particular, in some cases during periods of low settler abundance and percent cover, settler abundance for a single sampling date was zero. If bryozoan larvae preferentially settle at a particular location along the blade regardless of colony density, any observed patterns in settler abundance along the length of the blade should be consistent during periods of both high and low settlement and percent cover of bryozoan colonies.

Chi-squared goodness-of-fit tests were used to compare observed distributions of settlers among zones of kelp blades of increasing age with those expected by a random distribution. Although we collected blades of $S$. latissima $>100$ d old and of L. digitata $>300 \mathrm{~d}$ old, we only included blades of S. latissima and L. digitata that were 60-80 and 225-300 d old, respectively, in the analysis, to maximize the number of observations within each age category as well as the number of age categories. For September 2010 only, blades were included if they were 40 to $60 \mathrm{~d}$ old for S. latissima and 150 to $225 \mathrm{~d}$ old for L. digitata, because most plants collected at this time were younger or had experienced erosion of older blade tissue.

Sampling was conducted at 3 different depths at The Lodge to ensure representativity across the study site. However, because seasonal patterns in the abundance of $M$. membranacea settlers were consistent among depths (3-way ANOVA for unequal replication: $F_{2,218}=0.0315, \mathrm{p}=0.969$ ), measurements were pooled across depths.

We quantified percent cover of colonies of $M$. membranacea along the length of the kelp blade by calculating the average percent cover in each zone. For blades of $S$. latissima and $L$. digitata $<20 \mathrm{~cm}$ wide, the percent cover of $M$. membranacea colonies in each zone was averaged across sides of each 
blade. For blades of $L$. digitata $>20 \mathrm{~cm}$ wide, the percent cover of $M$. membranacea in each zone was first averaged across sides of 2 (if blade was 20 to $40 \mathrm{~cm}$ wide) or 3 (if blade was $>40 \mathrm{~cm}$ wide) segments of each blade, and then across the segments of each blade. Juvenile kelps (<30 $\mathrm{cm}$ in length) were not included when quantifying percent cover, since percent cover of bryozoans on their blades was highly variable. Typically, percent cover of bryozoans on juvenile kelps was 0 ; however, it could occasionally be $100 \%$, if a single colony of $M$. membranacea was established and grew to cover the entire surface area of the blade (D. Denley pers. obs.).
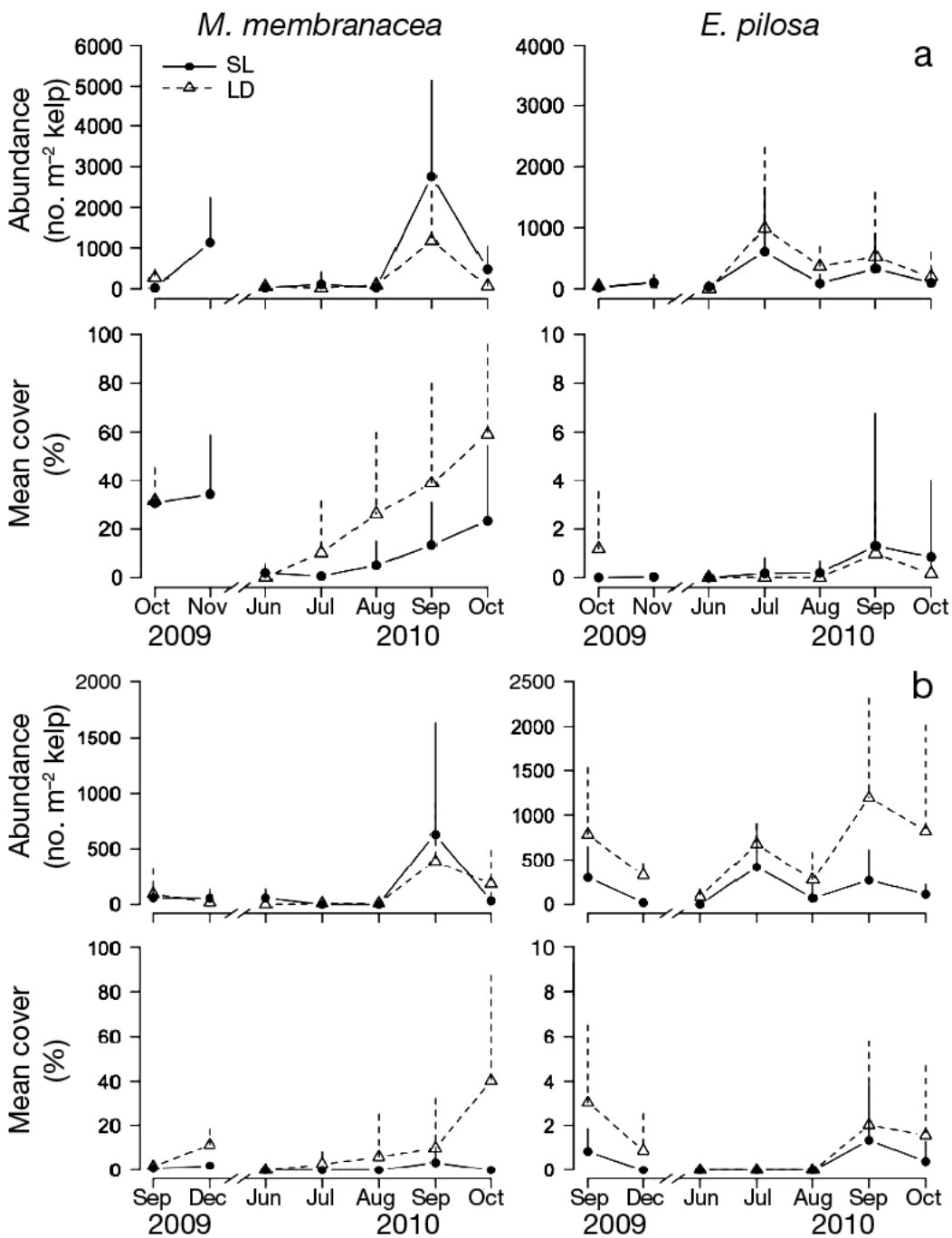

Fig. 1. (a) Membranipora membranacea and Electra pilosa abundance (mean $+\mathrm{SD}, \mathrm{n}=5$ to 30 kelps) of settlers and percent cover (mean $+\mathrm{SD}, \mathrm{n}=4$ to 29 kelps) of all colonies on Saccharina latissima (SL) and Laminaria digitata (LD) sampled at The Lodge in October and November 2009 and from June to October 2010. (b) M. membranacea and E. pilosa abundance (mean $+\mathrm{SD}, \mathrm{n}=4$ to 10 kelps) of settlers and percent cover (mean $+\mathrm{SD}, \mathrm{n}=4$ to 10 kelps) of all colonies on S. latissima and L. digitata sampled at Feltzen South in September and December 2009 and from June to October 2010

\section{RESULTS}

\section{Patterns in the abundance of settlers and colonies}

Overall, the pattern in settlement of Membranipora membranacea exhibited the typical timing and magnitude previously observed for this species in Nova cotia (Saunders \& Metaxas 2007, 2009a). Abuners of magnitude greater at The Lodge than at Feltzen South (Fig. 1). Abundance of settlers of Electra pilosa was highest slightly earlier, in July 2010, on both kelps at The Lodge and on Saccharina latissima at Feltzen South, but was higher in September 2010 on Laminaria digitata at Feltzen South (Fig. 1).

The peak abundance of settlers of M. membranacea was an order of magnitude greater than that of $E$. pilosa at The Lodge, but only on $S$. latissima (Fig. 1a). The opposite was observed at Feltzen South, where peak abundance of settlers of E. pilo$s a$ was an order of magnitude greater than that of $M$. membranacea, but only on L. digitata (Fig. 1b).

Seasonal patterns in percent cover of $M$. membranacea colonies differed slightly between sites; however, percent cover of colonies tended to increase in fall 2010 (Fig. 1). Cover of E. pilosa colonies was much lower than that of $M$. membranacea at both sites (Fig. 1).

\section{Patterns in settler abundance with increasing blade age}

Overall, when kelps of all ages were considered, there was a clear pattern of increasing relative abundance of settlers of M. membranacea and E. pilosa towards the younger, more proximal regions of the blade for both kelp species and at both sites over all sampling dates combined (Fig. 2). When considering only blades of $S$. latissima and $L$. digitata that were $60-80$ and 225-300 d old, respectively, settlers of M. membranacea were significantly 

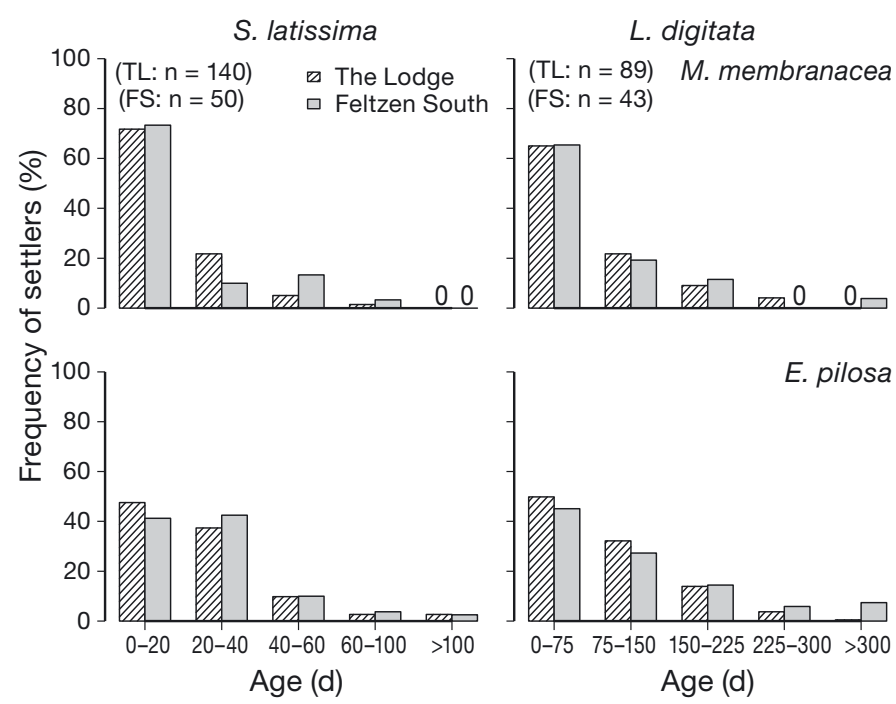

Fig. 2. Proportional abundance of settlers of Membranipora membranacea and Electra pilosa on zones of increasing age on blades of Saccharina latissima and Laminaria digitata sampled at The Lodge (TL) in October and November 2009 and from June to October 2010, and at Feltzen South (FS) in September and December 2009 and from June to October 2010, and including all sampled kelps of all ages. For each kelp species, proportional abundance is calculated for each zone across all collected kelps and pooled across dates and depths (TL only)

more abundant on younger regions and less abundant on older regions of the blades than expected for a random distribution for both kelp species and all sampling periods examined at both sites (Figs. 3 to 5, Table 1) except: (1) on S. latissima at Feltzen South for all dates combined (Fig. 3, Table 1) and (2) during low settler abundance and percent
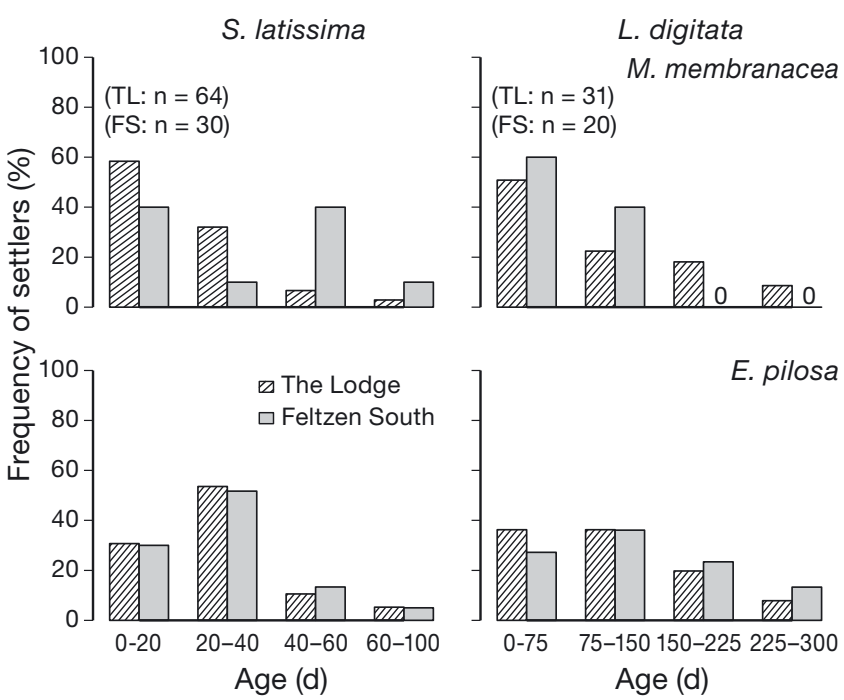

Fig. 3. Proportional abundance of settlers of Membranipora membranacea and Electra pilosa on blade segments of increasing age for Saccharina latissima 60 to $80 \mathrm{~d}$ old and Laminaria digitata blades 225 to $300 \mathrm{~d}$ old at The Lodge (TL) and Feltzen South (FS) calculated for the entire sampling period

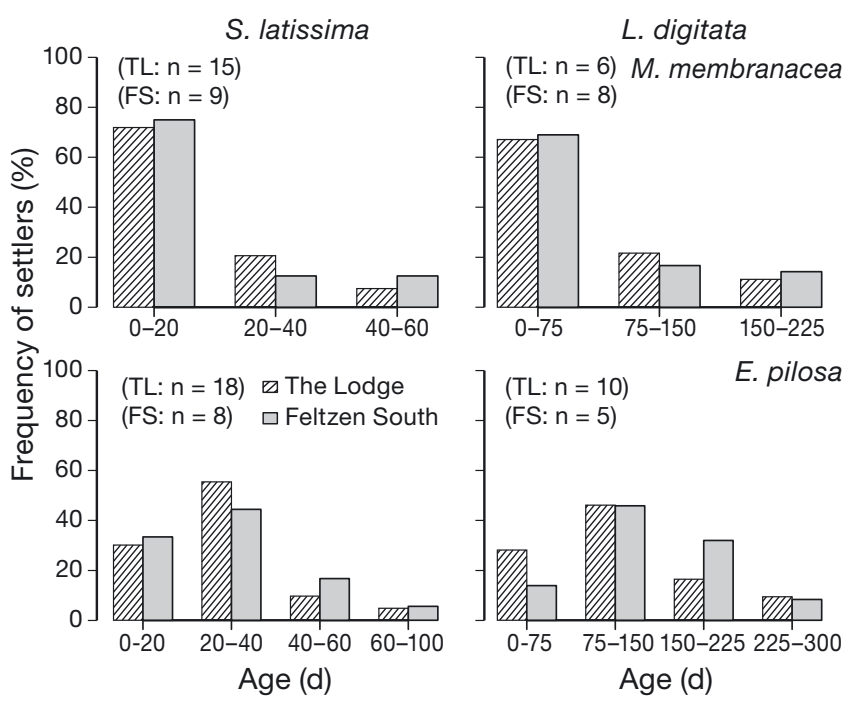

Fig. 4. Proportional abundance of settlers of Membranipora membranacea and Electra pilosa on blade segments of increasing age for Saccharina latissima and Laminaria digitata sampled during high settler abundance and percent cover at The Lodge (TL) and Feltzen South (FS) (M. membranacea: September 2010; E. pilosa: July 2010). For S. latissima, we only used blades that were 40 to $60 \mathrm{~d}$ old for the analysis on M. membranacea and 60 to $80 \mathrm{~d}$ old for E. pilosa. For L. digitata, we only used blades that were 150 to $225 \mathrm{~d}$ old for the analysis on $M$. membranacea and 225 to $300 \mathrm{~d}$ old for E. pilosa. See 'Materials and methods' for details

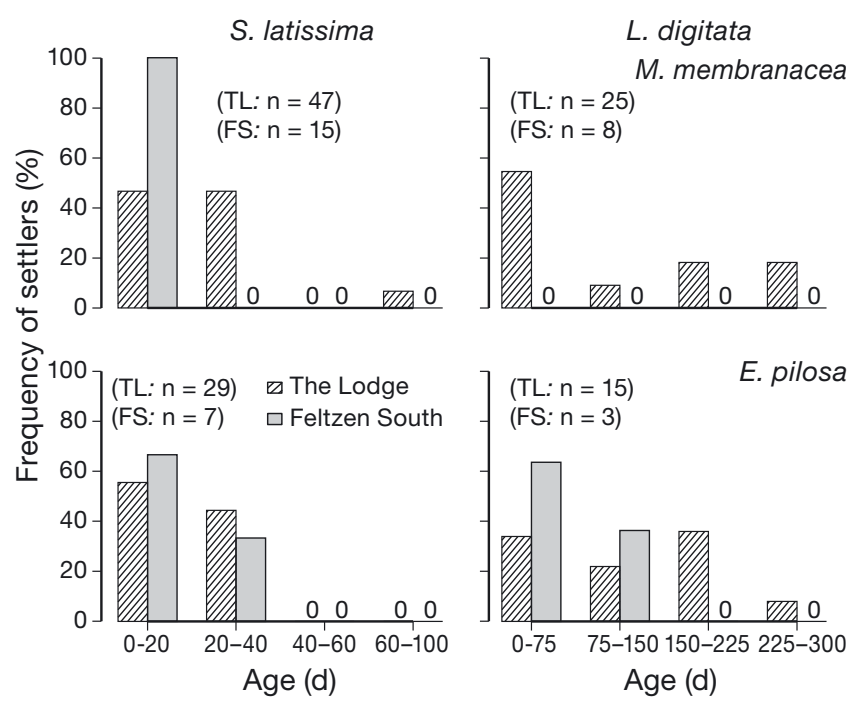

Fig. 5. Proportional abundance of settlers of Membranipora membranacea and Electra pilosa on blade segments of increasing age for Saccharina latissima and Laminaria digitata sampled during low settler abundance and percent cover at The Lodge (TL) and Feltzen South (FS) (M. membranacea: pooled June, July, and August 2010; E. pilosa: pooled June and August 2010). For S. latissima, we used blades that were 40 to $60 \mathrm{~d}$ old for the analysis on M. membranacea and E. pilosa. For L. digitata, we used blades that were 225 to $300 \mathrm{~d}$ old for the analysis on $M$. membranacea and E. pilosa. See 'Materials and methods' for details 
Table 1. Results of chi-squared goodness-of-fit tests used to compare the observed distributions of settlers of Membranipora membranacea $(\mathrm{Mm})$ and Electra pilosa (Ep) among zones of kelp blades of increasing age (4 categories) for Saccharina latissima (SL: 0-20, 20-40, 40-60, 60-80 d old) and Laminaria digitata (LD: 0-75, 75-150, 150-225, 225-300 d old) with those expected by a random distribution. Analyses were done for all sampling dates combined and for periods of high (Mm: September 2010; Ep: July 2010) and low (Mm: pooled June, July, and August 2010; Ep: pooled June and August 2010) settlement and percent cover. Significant p-values are shown in bold $(\alpha=0.05)$. NA: zero settler abundance

\begin{tabular}{|c|c|c|c|c|c|}
\hline Sampling date & Bryozoan & Site & Kelp & $\chi_{(\mathrm{df})}^{2}$ & $\mathrm{p}$ \\
\hline \multirow{6}{*}{$\begin{array}{l}\text { All dates } \\
\text { combined }\end{array}$} & \multirow[t]{3}{*}{$\mathrm{Mm}$} & $\mathrm{TL}$ & SL & $16.3_{(3)}$ & $<0.001$ \\
\hline & & & LD & $45.0_{(3)}$ & $<0.001$ \\
\hline & & FS & $\begin{array}{l}\text { SL } \\
\text { LD }\end{array}$ & $\begin{array}{l}3.60_{(3)} \\
10.8_{(3)}\end{array}$ & $\begin{array}{l}>0.05 \\
<\mathbf{0 . 0 2 5}\end{array}$ \\
\hline & \multirow[t]{3}{*}{ Ep } & TL & $\begin{array}{l}\text { SL } \\
\text { LD }\end{array}$ & $\begin{array}{l}65.9_{(3)} \\
50.3_{(3)}\end{array}$ & $\begin{array}{l}<0.001 \\
<0.001\end{array}$ \\
\hline & & FS & $\mathrm{SL}$ & $30.5_{(3)}$ & $<0.001$ \\
\hline & & & LD & $16.9_{(3)}$ & $<0.001$ \\
\hline \multirow{7}{*}{$\begin{array}{l}\text { High settlement } \\
\text { and percent cover }\end{array}$} & \multirow[t]{3}{*}{$\mathrm{Mm}$} & TL & SL & $158_{(2)}$ & $<0.001$ \\
\hline & & & & $+1.2_{(2)}$ & $<0.001$ \\
\hline & & FS & $\begin{array}{l}\text { SL } \\
\text { LD }\end{array}$ & $\begin{array}{l}12.5_{(2)} \\
24.1_{(2)}\end{array}$ & $\begin{array}{l}<0.001 \\
<0.001\end{array}$ \\
\hline & \multirow[t]{4}{*}{ Ep } & TL & SL & $53.0_{(3)}$ & $<0.001$ \\
\hline & & & LD & $39.6_{(3)}$ & $<0.001$ \\
\hline & & FS & SL & $12.9_{(3)}$ & $<0.001$ \\
\hline & & & LD & $25.5_{(3)}$ & $<0.001$ \\
\hline \multirow{7}{*}{$\begin{array}{l}\text { Low settlement } \\
\text { and percent cover }\end{array}$} & \multirow[t]{3}{*}{$\mathrm{Mm}$} & TL & SL & $11.4_{(3)}$ & $<0.01$ \\
\hline & & & LD & $5.35_{(3)}$ & $>0.05$ \\
\hline & & FS & $\begin{array}{l}\text { SL } \\
\text { LD }\end{array}$ & $\begin{array}{l}3.00_{(3)} \\
\text { NA }\end{array}$ & $\begin{array}{l}>0.05 \\
\text { NA }\end{array}$ \\
\hline & \multirow[t]{4}{*}{ Ep } & TL & SL & $18.4_{(3)}$ & $<0.001$ \\
\hline & & & LD & $10.0_{(3)}$ & $<0.025$ \\
\hline & & FS & SL & $3.66_{(3)}$ & $>0.05$ \\
\hline & & & LD & $12.6_{(3)}$ & $<0.01$ \\
\hline
\end{tabular}

cover (Fig. 5, Table 1); and (3) on L. digitata at The Lodge during low settler abundance and percent cover (Fig. 5, Table 1). In 2 of these 3 exceptions, the pattern was similar to that observed in the other cases, but was not detected statistically because of the low abundance of settlers.

The relative abundance of settlers of E. pilosa was greatest on blade tissue of young to intermediate age (20 to $40 \mathrm{~d}$ old for S. latissima and 75 to $150 \mathrm{~d}$ old for L. digitata) for both kelps and at both sites for the entire sampling period combined, and both during high and low settler abundance and percent cover (Figs. 3 to 5, Table 1), except on S. latissima at

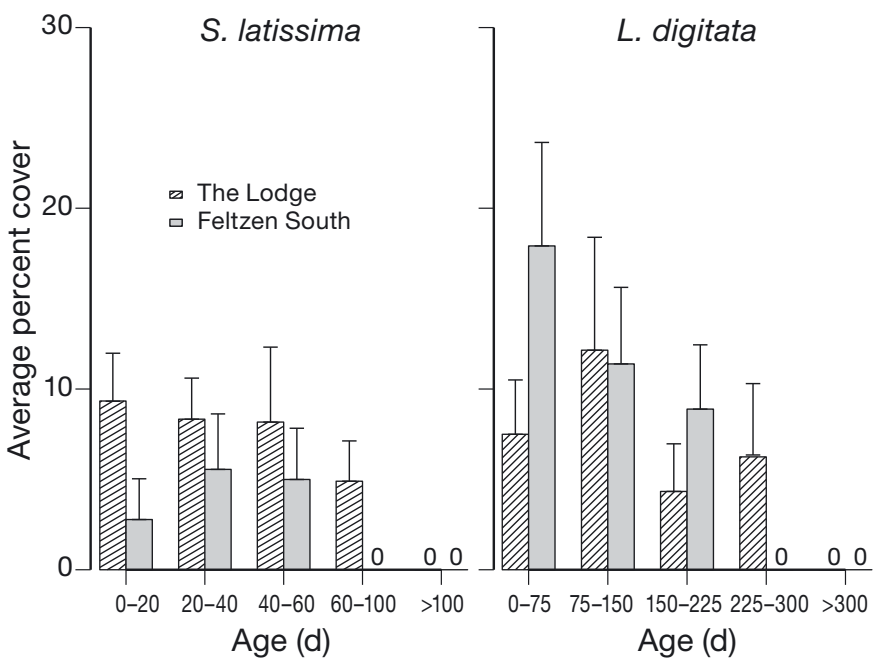

Fig. 6. Percent cover (mean $+\mathrm{SD}, \mathrm{n}=18$ to 36 kelps) of colonies of Membranipora membranacea on blade segments of increasing age for Saccharina latissima and Laminaria digitata $\geq 30 \mathrm{~cm}$ long, sampled during high percent cover and settler abundance of $M$. membranacea at The Lodge and Feltzen South (September 2010). Juvenile kelps $(<30 \mathrm{~cm}$ in length) were not included since percent cover of bryozoans on their blades was highly variable. See 'Materials and methods' for details

Feltzen South during low settler abundance and percent cover (Fig. 5, Table 1).

Percent cover of $M$. membranacea colonies did not vary consistently with blade age on either $S$. latissima or L. digitata at either site during peak settler abundance and cover of $M$. membranacea, except for L. digitata at Feltzen South where percent cover of M. membranacea appeared to decrease with increasing blade age (Fig. 6).

\section{DISCUSSION}

Settlers of Membranipora membranacea were most abundant towards the proximal end of the blade, except when their abundance was low, likely preventing the detection of patterns. Settlers of Electra pilosa were also most abundant towards the proximal end of the blade; however, E. pilosa settlers were distributed across a wider age range of blade tissue than settlers of $M$. membranacea. Percent cover of $M$. membranacea colonies during high settler abundance and cover was fairly uniform along the length of the kelp blades. This suggests that the distribution of settlers towards the proximal end of kelp blades reflects a preference for settlement on younger algal tissue by bryozoan larvae, rather than space limitation or gregariousness. It is important to note when 
considering kelps of all ages, that although few collected kelps were $>100 \mathrm{~cm}$ in length, the majority of kelps sampled were long enough to detect the transition from high to low abundance of settlers, with settler abundance reaching zero well before the end of the blade.

High abundance of settlers near the base of fronds of Saccharina latissima and Laminaria digitata have also been observed for the bryozoan Scrupocellaria reptans in the northeastern Atlantic (Ryland \& Stebbing 1971). In the laboratory, settlement preference experiments indicated that significantly more larvae of $S$. reptans settled on disks of L. digitata cut from younger regions of the blade than those from older regions when presented with a choice (Stebbing 1972). Similarly, larvae of the bryozoan Lichenopora novae-elandiae have been shown to preferentially settle on younger sections of the brown alga Agarum fimbriatum in Barkley Sound, Vancouver Island (Durante \& Chia 1991).

By settling on younger, more proximal regions of kelp blades, larvae of $M$. membranacea have access to an intact, stable substrate for the longest period of time possible, thereby increasing the maximum colony size that can be attained. In turn, this will maximize colony fecundity (Yoshioka 1973, Harvell et al. 1990). However, the most common agent of obstructed colony growth for $M$. membranacea is crowding by conspecifics. Although mortality due to overgrowth among colonies of $M$. membranacea is rare, growth along margins of colony contact ceases, and obstructed growth during periods of high colony density can severely limit individual colony size (Harvell et al.1990). As a result, recruits of M. membranacea are smaller in high-density populations than those in low-density populations (Ellison \& Harvell 1989). Although percent cover of $M$. membranacea colonies did not vary consistently with blade age, it is possible that the size distribution of colonies did. Growth of $M$. membranacea colonies is positively related to colony size (Saunders \& Metaxas 2009b); therefore, larger colonies tend to dominate in competition for available space. If smaller, more recently established colonies are concentrated towards the proximal region of kelp blades, it would be advantageous for larvae of $M$. membranacea to settle preferentially on younger regions of the blade, where competition for space and crowding by conspecifics is reduced.

In contrast, the slow growth rates and low colony abundance of E. pilosa on kelp suggests that intraspecific competition for space among conspecifics is weak for this species. Settlement preference for younger parts of the blades of $S$. latissima and L. digi- tata may instead be driven primarily by the longevity of the substrate. The comparatively slower growth rate of E. pilosa may indicate a longer time to maturity for this species. If that is the case, the reproductive success of individual E. pilosa colonies may be strongly dependent on the duration of the substrate onto which they initially settle, which may explain the higher abundance of E. pilosa on more stable, slower-growing fucoid species than on fastergrowing, more ephemeral kelp substrates in Nova Scotia (Yorke \& Metaxas 2011).

The higher abundance of settlers of E. pilosa slightly further from the proximal end of the blade towards tissue of a young to intermediate age may reflect $E$. pilosa being out-competed by $M$. membranacea on the more favorable proximal blade tissue. M. membranacea has been shown to be competitively superior to E. pilosa on kelps in the northwest Atlantic (Berman et al. 1992); however, M. membranacea does not always overgrow E. pilosa upon encounter, and standoffs between the 2 species occur more frequently than would be expected if M. membranacea was competitively dominant (Yorke \& Metaxas 2011).

The mechanisms by which competent larvae detect variations in microhabitat within the bounds of an individual kelp blade are unclear. Brown algae are known to produce secondary metabolites as a chemical defense against herbivory (Van Alstyne et al. 1999) and, in some cases, these or similar compounds have been shown to deter epiphytism by fouling organisms (Schmitt et al. 1995, but see Jennings \& Steinberg 1997). For 21 species of laminarian kelps and rockweeds, Van Alstyne et al. (1999) found that meristematic tissue tended to have higher phlorotannin levels than non-meristematic vegetative tissues. In Nova Scotia, high concentrations of polyphenolic compounds have been detected in the meristem of S. latissima, where they were shown to deter grazing by the mesogastropod Lacuna vincta (Johnson \& Mann 1986). However, this distribution of secondary metabolites, with higher levels towards the basal meristem of the blade, is inconsistent with chemical inhibition of $M$. membranacea and E. pilosa, for which settler abundance actually increases towards the proximal regions of $S$. latissima and $L$. digitata. It may be that their chitinous exoskeleton renders these bryozoans more resistant to secondary metabolites. Anti-fouling metabolites extracted from the red alga Dilsea carnosa off the west coast of Sweden inhibited recruitment of some fouling organisms, but were ineffective against fouling by $M$. membranacea and E. pilosa (Nylund \& Pavia 2005) 
The distribution of microflora along the length of the blade may affect settlement of larval epibionts (Stebbing 1972). Since the spatial patterns in microflora along a kelp blade are likely correlated with its age, the presence or absence of a particular taxon may be used as a cue for younger tissue. For example, bacterial abundance and community composition were found to vary with tissue age on L. digitata (Corre \& Prieur 1990); however, whether these variations are substantial enough to be detectable by bryozoan larvae is not known. Larvae of $\mathrm{M}$. membranacea exhibit small-scale active searching behavior upon contact with a presumably high-quality habitat (Matson et al. 2010). Specifically, larvae of $M$. membranacea have been observed to move from older more distal regions to younger more proximal regions of the blades of Nereocyctis luetkeana in a flume in the laboratory (Matson et al. 2010). However, this may have been a response to the direction of flow along the blade rather than the physical characteristics of the algae. Although we did not measure flow either on the scale of the blade or at our study sites, kelp blades tend to be long and broad at The Lodge and Feltzen South, morphologies indicative of kelps from low-energy environments (Gerard \& Mann 1979). Under these conditions, flow velocity may be too weak and/or too variable to provide a consistent directional cue for searching larvae, particularly at the level of the kelp blade.

In conclusion, we clearly demonstrated that larvae of the dominant species of bryozoans in Nova Scotia, M. membranacea and E. pilosa, exhibit a preference for settling towards younger, more proximal regions on the blades of the numerically dominant kelps $S$. latissima and L. digitata. This preference appears to be independent of colony density, but may require a threshold level of settler abundance to be detected. While the mechanisms for settlement preference remain unclear, variation in the chemical composition of the substrate or the microfloral community along the blade are likely significant factors. Our findings suggest that post-settlement events, such as competition for space among conspecifics and colony longevity, as it relates to the duration of substrate availability, can influence the evolution of selective settlement behavior in sessile marine epiphytes with planktonic larvae.

Acknowledgements. John Lindley, Kira Krumhansl, Karen Filbee-Dexter and Michelle Lloyd provided field assistance. Robert Scheibling provided comments on an earlier version of this manuscript. This research was supported by a Natural Sciences and Engineering Research Council (NSERC) Discovery grant to A.M., a Fellowship from the Dalhousie Faculty of Graduate Studies to D.D., and a NSERC USRA to J.S.

\section{LITERATURE CITED}

Berman J, Harris L, Walter L, Buttrick M, Dufresne, M (1992) Recent invasions of the Gulf of Maine: three contrasting ecological histories. Conserv Biol 6:435-441

Bernstein BB, Jung N (1979) Selective pressures and coevolution in a kelp canopy community in Southern California. Ecol Monogr 49:335-355

Bolton JJ, Lüning K (1982) Optimal growth and maximal survival temperatures of Atlantic Laminaria Species (Phaeophyta) in culture. Mar Biol 66:89-94

Burke RD (1983) The induction of metamorphosis of marine invertebrate larvae: stimulus and response. Can J Zool 61:1701-1719

Chia FS (1989) Differential larval settlement of benthic marine invertebrates. In: Ryland JS, Tyler PA (eds) Reproduction, genetics and distributions of marine organisms. Olsen \& Olsen, Fredensborg, p 3-12

Corre S, Prieur D (1990) Density and morphology of epiphytic bacteria on the kelp Laminaria digitata. Bot Mar 33:515-523

> Durante MK, Chia FS (1991) Epiphytism on Agarum fimbriatum: Can herbivore preferences explain distributions of epiphytic bryozoans? Mar Ecol Prog Ser 77:279-287

$>$ Ellison AM, Harvell CD (1989) Size hierarchies in Membranipora membranacea: Do colonial animals follow the same rules as plants? Oikos 55:349-355

$>$ Gerard VA, Mann KH (1979) Growth and production of Laminaria longicruris (Phaeophyta) populations exposed to different intensities of water movement. J Phycol 15: 33-41

Hadfield MG (1986) Settlement and recruitment of marine invertebrates: a perspective and some proposals. Bull Mar Sci 39:418-425

> Harvell CD, Caswell H, Simpson P (1990) Density effects in a colonial monoculture: experimental studies with a marine bryozoan (Membranipora membranacea L.). Oecologia 82:227-237

Hayward PJ, Harvey PH (1974) Distribution of settled larvae of bryozoans Alcyonidium hirsutum (Fleming) and Alcyonidium polyoum (Hassall) on Fucus serratus L. J Mar Biol Assoc UK 54:665-676

> Jennings JG, Steinberg PD (1997) Phlorotannins versus other factors affecting epiphyte abundance on the kelp Ecklonia radiata. Oecologia 109:461-473

Johnson CR, Mann KH (1986) The importance of plant defense abilities to the structure of subtidal seaweed communities: the kelp Laminaria longicruris de la Pylaie survives grazing by the snail Lacuna vincta (Montagu) at high population densities. J Exp Mar Biol Ecol 97: 231-267

> Keough MJ (1986) The distribution of a bryozoan on seagrass blades: settlement, growth, and mortality. Ecology 67:846-857

> Keough MJ, Downes BJ (1982) Recruitment of marine invertebrates: the role of active larval choices and early mortality. Oecologia 54:348-352

> Krumhansl KA, Scheibling RE (2011) Detrital production in Nova Scotian kelp beds: patterns and processes. Mar Ecol Prog Ser 421:67-82

> Krumhansl KA, Lee MJ, Scheibling RE (2011) Grazing damage and encrustation by an invasive bryozoan reduce the ability of kelps to withstand breakage by waves. J Exp Mar Biol Ecol 407:12-18

> Lambert WJ, Levin PS, Berman J (1992) Changes in the 
structure of a New England (USA) kelp bed: the effects of an introduced species? Mar Ecol Prog Ser 88:303-307

Mann KH (1973) Seaweeds: their productivity and strategy for growth. Science 182:975-981

Matson PG, Steffen BT, Allen RM (2010) Settlement behavior of cyphonautes larvae of the bryozoan Membranipora membranacea in response to two algal substrata. Invertebr Biol 129:277-283

Minchinton TE, Scheibling RE (1991) The influence of larval supply and settlement on the population structure of barnacles. Ecology 72:1867-1879

Nylund GM, Pavia H (2005) Chemical versus mechanical inhibition of fouling in the red alga Dilsea carnosa. Mar Ecol Prog Ser 299:111-121

Roland W (1980) Epiphytism and endophytism of Macrocystis integrifolia and Nereocystis luetkeana: seasonality, succession and tactics on temporary, living substrate. MSc dissertation, Simon Fraser University, Burnaby

Ryland JS, Stebbing ARD (1971) Settlement and orientated growth in epiphytic and epizoic bryozoans. In: DJ Crisp (ed) Fourth European marine biology symposium. Cambridge University Press, Cambridge, p 105-123

Saunders M, Metaxas A (2007) Temperature explains settlement patterns of the introduced marine bryozoan Membranipora membranacea in Nova Scotia, Canada. Mar Ecol Prog Ser 344:95-106

Saunders M, Metaxas A (2008) High recruitment of the introduced bryozoan Membranipora membranacea is associated with kelp bed defoliation in Nova Scotia, Canada. Mar Ecol Prog Ser 369:139-151

Saunders M, Metaxas A (2009a) Population dynamics of a nonindigenous epiphytic bryozoan Membranipora membranacea in the western North Atlantic: effects of kelp substrate. Aquat Biol 8:83-94

Saunders M, Metaxas A (2009b) Effects of temperature, size, and food on the growth of Membranipora membranacea in laboratory and field studies. Mar Biol 156:2267-2276

Scheibling RE, Gagnon P (2009) Temperature-mediated out-

Editorial responsibility: Judith Grassle,

New Brunswick, New Jersey, USA break dynamics of the invasive bryozoan Membranipora membranacea in Nova Scotian kelp beds. Mar Ecol Prog Ser 390:1-13

> Scheibling RE, Hennigar AW, Balch T (1999) Destructive grazing, epiphytism, and disease: the dynamics of sea urchin-kelp interactions in Nova Scotia. Can J Fish Aquat Sci 56:2300-2314

> Schmitt TM, Hay ME, Lindquist N (1995) Constraints on chemically mediated coevolution: multiple functions for seaweed secondary metabolites. Ecology 76:107-123

Seed R (1976) Observations on the ecology of Membranipora (Bryozoa) and a major predator Doridella steinbergae (Nudibranchiata) along the fronds of Laminaria saccharina at Friday Harbor, Washington. J Exp Mar Biol Ecol 24:1-17

Seed R, O'Connor RJ (1981) Community organization in marine algal epifaunas. Annu Rev Ecol Syst 12:49-74

$>$ Stebbing AR (1972) Preferential settlement of a bryozoan and serpulid larvae on younger parts of Laminaria fronds. J Mar Biol Assoc UK 52:765-772

Van Alstyne KL, McCarthy JJ, Hustead CL, Kearns J (1999) Phlorotannin allocation among tissues of northeastern Pacific kelps and rockweeds. J Phycol 35:483-492

Watanabe S, Scheibling RE, Metaxas A (2010) Contrasting patterns of spread in interacting invasive species: Membranipora membranacea and Codium fragile off Nova Scotia. Biol Invasions 12:2329-2342

> Yorke AF, Metaxas A (2011) Interactions between an invasive and native bryozoan (Membranipora membranacea and Electra pilosa) species on kelp and Fucus substrates in Nova Scotia, Canada. Mar Biol 158:2299-2311

> Yorke AF, Metaxas A (2012) Relative importance of kelps and fucoids as substrata of the invasive epiphytic bryozoan Membranipora membranacea in Nova Scotia, Canada. Aquat Biol 16:17-30

Yoshioka PM (1973) The population dynamics and ecology of the encrusting ectoproct Membranipora serrilamella. $\mathrm{PhD}$ dissertation, University of California, San Diego, CA

Submitted: July 1, 2013; Accepted: April 16, 2014

Proofs received from author(s): June 11, 2014 